\title{
Studying the Hypoglycemic Activity of Celery Herb Extract Apium graveolens in Blood Glucose Level of Laboratory Rats (Sprague Dawely)
}

\author{
Rafid Mohammed Ali Hassan Wasfi ${ }^{1 *}$ (D) and Yarob Saad Abdil-Jaleel AL-kabi ${ }^{2}$ \\ ${ }^{1}$ Department of Clinical Laboratory Science, ${ }^{2}$ Depatrment of Pharmacology and Toxicology Faculty of Pharmacy, \\ Kufa University, Iraq.
}

\begin{abstract}
The current study aimed to evaluate the effect of methanolic extract of celery herb Apium graveolens in blood glucose level of the laboratory rats. $300 \mathrm{mg} / \mathrm{kg}$ of plant extract was detected. The blood glucose level was measured after 3, $6 \mathrm{hrs}$. for the extract and glibenclamide drug treatment. The result showed that both the extract and glibenclamide had hypoglycemic activity compared with control group. The result showed that there is significant hypoglycemic activity for celery extract and glibenclamid drug specially after $6 \mathrm{hrs}$ of the treatment.
\end{abstract}

Keyword: Diabetes, Apium graveolens, celery, hypoglycemic activity.

*Correspondence: rafidm.abed@uokufa.edu.iq

(Received: 01 November 2019; accepted: 21 December 2019)

Citation: Rafid Mohammed Ali Hassan Wasfi and Yarob Saad Abdil-Jaleel AL-kabi, Studying the Hypoglycemic Activity of Celery Herb Extract Apium graveolens in Blood Glucose Level of Laboratory Rats (Sprague Dawely), J Pure Appl Microbiol., 2019; 13(4): 2389-2395. https://doi.org/10.22207/JPAM.13.4.55

(C) The Author(s) 2019. Open Access. This article is distributed under the terms of the Creative Commons Attribution 4.0 International License which permits unrestricted use, sharing, distribution, and reproduction in any medium, provided you give appropriate credit to the original author(s) and the source, provide a link to the Creative Commons license, and indicate if changes were made. 


\section{INTRODUCTION}

Diabetes is a chronic disease refers to the absolute lack of insulin. The clinical appearances are caused the glucose intolerance lead to hyperglycemia and changing in lipid and protein metabolism. Diabetes has two types of disorders. All types of diabetes mellitus can be referred to type 1 or type 2 diabetes. It seems that about $5 \%$ to $10 \%$ of the diagnosed people has type 1 diabetes, which usually caused by the destruction by the immunity of the pancreatic $\beta$-cells ${ }^{1,2}$. Plants extract have usually been used as a source for drugs. The herbal drugs have been tested around the worlds to cure diabetes ${ }^{3,4}$. However, the benefit of their use is lower adverse effects that are clearly seen during use the chemical medicines ${ }^{5,6}$. Although the traditional hypoglycemic medicines that is reducing blood glucose may caused upsetting side effects. Discovery other anti-diabetes agents, especially those made from natural sources is preferred7. Celery originated as a wild plant growing in salt marshes in of the Mediterranean Sea ${ }^{8,9}$. Wild celery $A$. graveolens is an aquatic perennial herb ${ }^{10}$. Previous studies revealed that the juice decrease blood pressure in many patient ${ }^{11,12}$. This effect may be resulted from the chemical composition which contain about twenty compounds were obtained and recognized ${ }^{13-16}$. Accordingly the present study aimed to studying the hypoglycemic effect of alcoholic extract of celery herb.

\section{MATERIALS AND METHODS}

Methanol extract preparation of celery herb was performed According to ${ }^{17}$. Celery $A$. graveolens herb brought from the local market. The herb powdered in room temperature using grinder. Then $50 \mathrm{~g}$ of the preparing Powdered were dissolved in $500 \mathrm{ml}$ of methanol and extracted by soxhlet for $12 \mathrm{hrs}$. The suspension was filtered and the remains was once more extracted in equivalent amount of methanol for $12 \mathrm{hrs}$ and again filtered. The filtrates was obtained, evaporated and dried by distillation with reducing pressure at 40 to $50^{\circ} \mathrm{C}$ in rotary evaporator ${ }^{18}$.

\section{Laboratory animals}

Twenty five male rats (Sprague Dawely) the weight ranging between 180 to 250 grams from the animal house of faculty of pharmacy university of Kufa .
Animal were housed at a controlling condition with approval of the animal ethical comity university of Kkufa. The rats were divided in to five groups. Five animals were assembled in each group

Diabetes mellitus induction

Induction of diabetes mellitus was made by intraperitoneal injection of alloxan monohydrate. It is a toxic glucose analogue. It is selectively destroys insulin-producing cells in the pancreas when the rodent are treated in this material as many other animal species. It causes an insulin dependent diabetes mellitus called alloxan diabetes $^{19}$. After 7 days and diabetes mellitus was measured using Glucometer device ${ }^{20}$. The Animals with blood glucose level higher than $200 \mathrm{mg} / \mathrm{dl}$ were chosen for our research study. The animals were given $20 \%$ of glucose in drinking container of the animal along the days of experiment. Series of doses experiment were used to determine the therapeutic doses. Then animals were treated as the following:-

1. The Extract Group: Rats were treated orally with of $300 \mathrm{mg} / \mathrm{kg}$ of $A$. graveolens extract dissolved in $4 \mathrm{ml}$ of normal saline byusing stomach tube.

2. The glibenclamide group treated with of $(0.8 \mathrm{mg} / \mathrm{kg})$ of glibenclamide as blind control.

3. The control group treated with $(4 \mathrm{ml})$ of normal saline orally. After the glucose level was measured during ( 3 and 6 hours) of treatment by collecting $(1 \mathrm{ml})$ of Blood directly from the heart for all groups.

\section{Statistics}

The differences between the treatments was calculated by applying one way ANOVA using SPSS version 25.000 (2018) program. The $p$ value $\leq 0.05$ was chosen to determine significant differences.

\section{RESULT AND DISCUSSION}

As it appear in Fig. 1 there was a significant $p \leq 0.05$ increasing in blood glucose level in the group treated with alloxan compared with control group. While Fig. 2 showed that there is no significant decreasing in blood glucose level in the diabetic group treated with plant extract compared with control group(normal saline) after $3 \mathrm{hr}$ of the treatment. The result in Fig. 3 showed no significant decreasing in blood glucose in the 


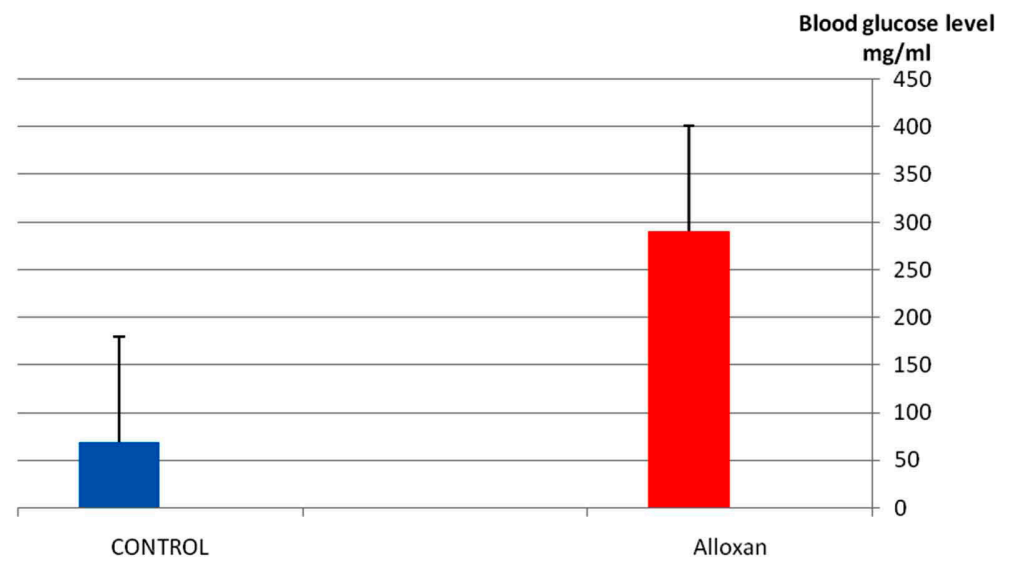

Fig. 1. Effect of alloxan in blood glucose level of laboratory rats $n=5$

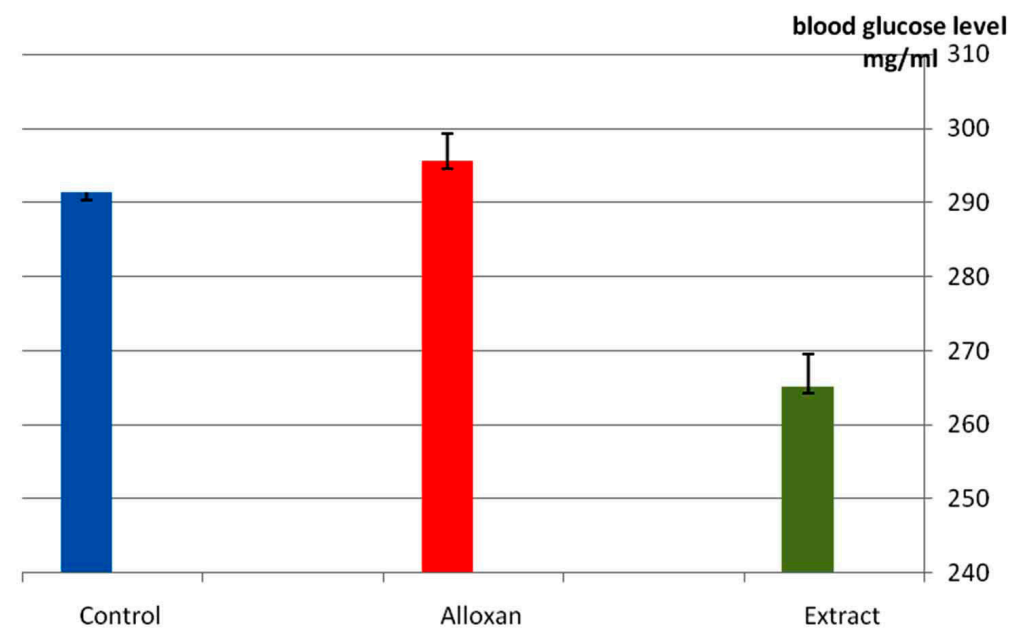

Fig. 2. Effect of the extract in blood glucose level of laboratory rats after 3hrs of treatment $n=5$

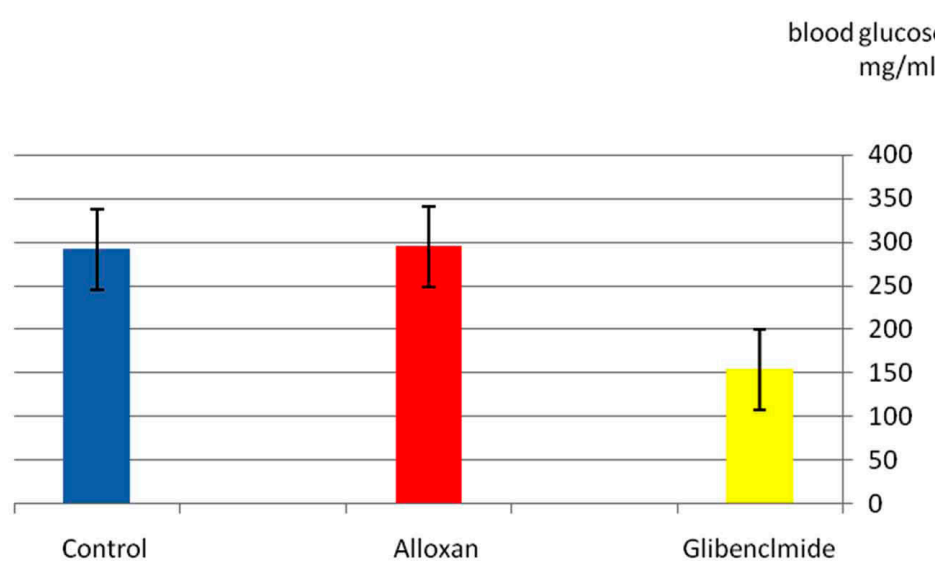

Fig. 3. Effect of glibenclamide drug in blood glucose level of laboratory rats after 3 hrs of treatment $n=5$ 
diabetic group treated with glibenclamide drug compared with control group (normal saline) after 3 hrs of the treatment. While Fig. 4 showed a significant decreasing $\mathrm{p} \leq 0.05$ in blood glucose level in the group treated with the extract compared with control group. Fig. 5 indicates that there is considerable decreasing $p \leq 0.05$ in the blood glucose level in the group treated with glibenclamide drug compared with control group. Fig. 6 showed the comparison in the hypoglycemic activity between the group treated with extract and glibenclamide drug .Its indicates a significant decreasing $\mathrm{p} \leq 0.05$ in blood glucose level in the group treated with glibeclamide drug compared with the group treated the extract. Alloxans compound used in medicinal research it is quick and convenient method for producing experimental diabetes in laboratory animal. As with other alkylting agents has cytotoxic effect causing DNA destruction or by other mechanisms which may also lead to the DNA damage ${ }^{21,22}$. Thus the injection of alloxan may cause diabetes mellitus. Three phases are generally observed after the administration of alloxan, transitory periods of hyperglycemia and hypoglycemia followed by permanent hyperglycemia and other diabetic symptoms. Alloxan thought to act directly and specifically on the pancreatic insulin secreting $\beta$ - cell, causing them to undergo degeneration and resorption This effect is obvious by the increasing level of blood glucose in animals treated with alloxan ${ }^{23}$. The result in Fig. 2, 3 showed no significant hypoglycemic effect after 3 hrs of treatment this may due to low metabolism of plant extract and it may take a long time to show its effect ${ }^{24}$. The result in Fig. 4, 5 showed significant hypoglycemic activity in both plant extract and glibenclamid drug groups compared with control group after 6hrs of treatment. This activity may indicates a hypoglycemic effect in the plant extract

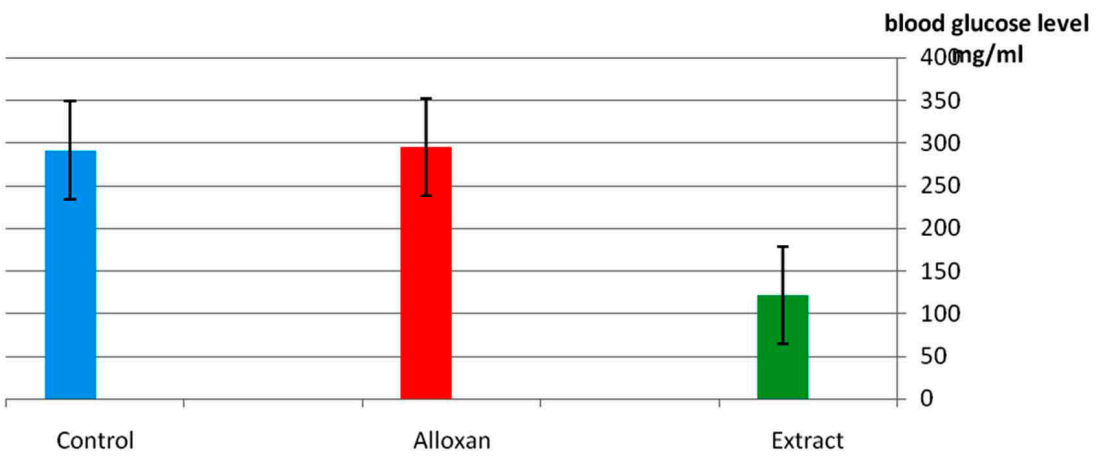

Fig. 4. Effect of the extract in blood glucose level of laboratory rats. After 6hrs of treatment $n=5$

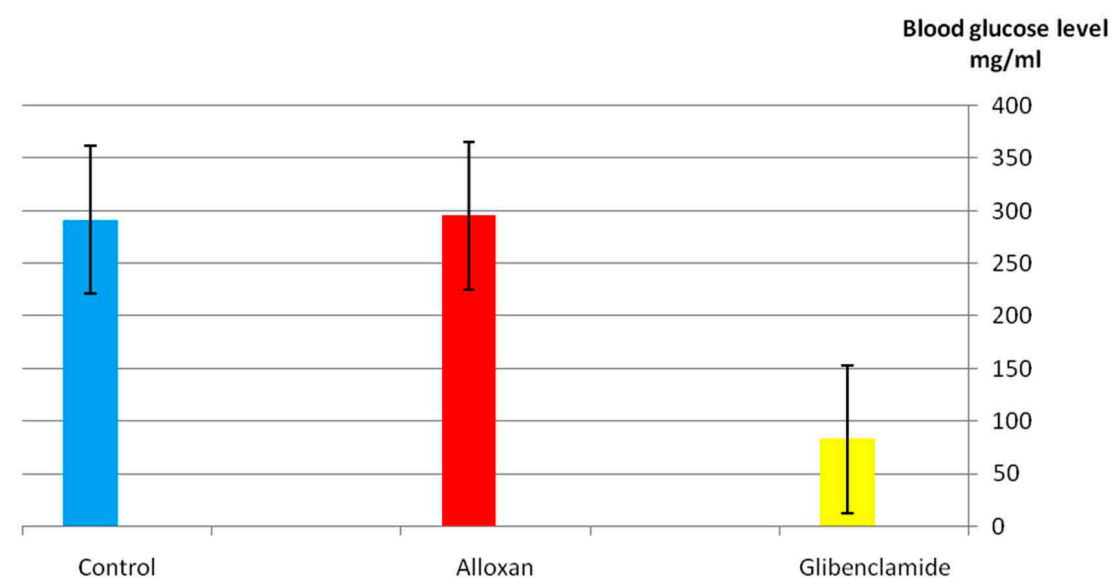

Fig. 5. Effect of the glibenclamide drug in blood glucose level of laboratory rats after 6 hrs of treatment $n=5$ 


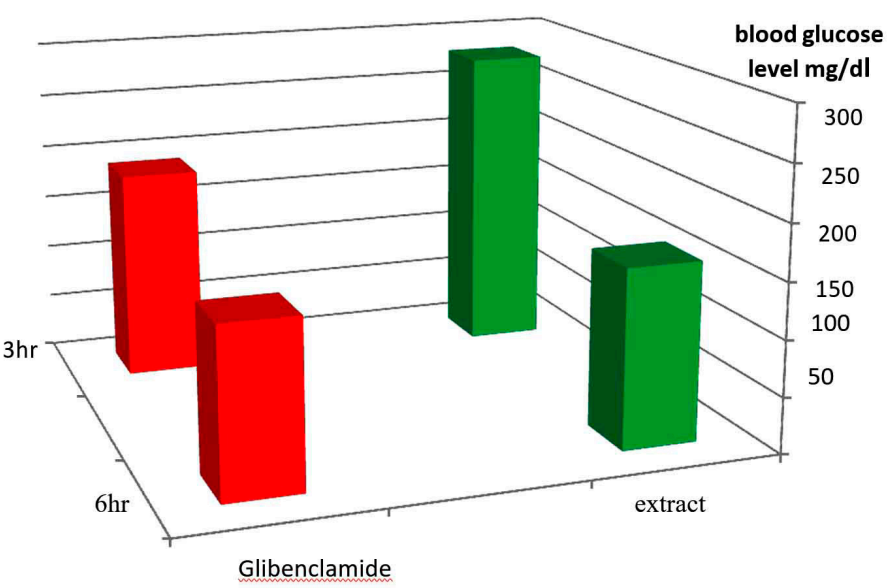

Fig. 6. comparison the effect of the extract and glibenclamide drug in blood glucose level after $(3,6)$ hr in laboratory rats $n=5$

this activity may related of the ability of the celery extract to works at lowering blood glucose levels by affecting the absorption of glucose in the intestine, not by stimulating the production of insulin by the pancreas ${ }^{25,26}$. Fig. 6 showed highly significant hypoglycemic activity of glibenclamide when it compared with plant extract. The low hypoglycemic activity of plant extract may due to the lower component of active ingredients in the crude plant extract. This agree with ${ }^{27}$. Who suggest that Celery plant extracts have hypertensive and hypoglycemic effects? Or may be due to phthalide constituents ( $d$ - limonene, selinene, and related phthalides). The ability to reduce of blood glucose of the plant extract may due to the stimulation to the $\lambda$-cells to secrete insulin ${ }^{28}$. The rising of repair or propagation of $\beta$-cells increased the effect of insulin and raising the oxidative capability which in turn, increases the utilization of glucose by the cells ${ }^{29}$. Extra pancreatic mechanisms for example improved glucose transport into the cells and better formation of glycogen in the liver cell may be involved in induced the decrease in blood glucose level ${ }^{30-32}$.

\section{CONCLUSION}

The plant $A$. graveolens may has hypoglycemic activity since its. A natural product and further studies need to evaluate its activity.

\section{Recommendation}

Further studies may be warranted to identify the possible mechanism of the plant by including the parameters like insulin, C-peptide and also histopathology of pancreas.

\section{ACKNOWLEDGEMENTS}

The authors Rafid and yarob are thankful to Dr. Ali Aboud Shareef for his effort in the classification of the Plant and are also thankful to the Dr. Ahmed Jala the head of the department clinical laboratory science in the faculty of pharmacy in the university of kufa for his support

\section{CONFLICT OF INTEREST}

The authors declare that there is no conflict of interest.

\section{FUNDING}

None.

\section{AUTHOR'S CONTRIBUTION}

RMAHW contributed by preparing the laboratory animal and the treatment of them and all the practical side of the research. YSAA analyzed the data and helped in preparation of figures, interpretation and drafted the manuscript. Both authors read and approved the manuscript for publication.

\section{DATA AVAILABILITY}

All datasets generated or analyzed during this study are included in the manuscript. 


\section{ETHICS STATEMENT}

This paper was approved by the local ethical committee of kufa university which Dr. Rafid one of the researcher is amember in this committee according to report in number 16081 in 30/6/2019.

\section{REFERENCES}

1. Ronald Goldenberg and, Zubin Punthakee. Definition, Classification and Diagnosis of Diabetes, Prediabetes and Metabolic Syndrome Can. J. Diabetes, 2013; 37: S8-S11. https://doi.org/10.1016/j.jcjd.2013.01.011

2. Kaushik G, Satya S, Khandelwal RK, and Naik SN. Commonly consumed Indian plant food materials in the management of diabetes mellitus. Diabetes Metab. Syndr.; 2010; 4: 21-40. https://doi.org/10.1016/j. dsx.2008.02.006

3. Hnatyszyn O, Mino J, Ferraro G, and Acevedo C. The hypoglycemic effect of Phyllanthus sellowianus fractions in streptozotocin induced diabetic mice. Phytomedicin, 2009; 9: 556-559. https://doi. org/10.1078/09447110260573209

4. Hillay JE, Tahraoui A, Israili ZH, and Lyouui B. Hypolipidemic effects of acute and sub chronic administration of an aqueous extract of Ajugaiva L. whole plant in normal and diabetic rats.; J. Ethnopharmacol.; 2006; 105: 441-448. https://doi. org/10.1016/j.jep.2005.11.023

5. May L, Lefkowitch J, Kram M, Rubin D. Mixed hepato cellular cholestatic liver injury after pioglitazone therapy.; Ann. Intern. Med.; 2002; 136: 449452. https://doi.org/10.7326/0003-4819-136-6200203190-00008

6. Bhatnagar D. Lipid-lowering drugs in the management of hyperlipidaemia. Pharmacol. Ther.; 1998; 79: 205230. https://doi.org/10.1016/S0163-7258(98)00018-7

7. Vishwakarma SL, Rakesh S, Rajani M, and Goyal RK. Evaluation of effect of aqueous extract of Enicostemma littorale Blume. In streptozotocin induced type 1 diabetic rats.; Indian J. Exp. Biol.; 2010; 48: 26-30.

8. Von Norman G.B. and Max W. Herbal Drugs and Phytopharmaceuticals Medpharm ed. Scientific Publ., 1994.

9. Garfield E. From Tonic to Psoriasis Stalking Celery's Secrets. Current Contents, 1985; 16(8): 3.

10. Lin LZ, Lu S. and, Harnly M. Detection and quantification of glycosylated flavonoid malonates in celery, chinese celery, and celery seeds by lc-dad-esi/ms.; J. Agric. Food Chem., 2007; 55: 1321-26. https://doi. org/10.1021/jf0624796

11. Alaaeldin A. Hamza and Amr Amin. Apium graveolens modulates sodium valproate-induced reproductive toxicity in rats., Journal of Experimental Zoology Part A: Ecological Genetics and Physiology, 2000; 307A: 199-206. https://doi.org/10.1002/jez.357

12. Anubha, Singh and SS, Handa, Hepatoprotective activity of Apium graveolens and Hygrophila auriculata against paracetamol and thioacetamide intoxication in rats. Journal of Ethnopharmacology, 1995; 49(3):
Pages 119-126. https://doi.org/10.1016/03788741(95)01291-5

13. Zho ngguo Zhong and Yao Za Zhi, Chemical constituents of fresh celery. Zhongguo Zhong Yao Za Zhi. Jun., 2009; 34(12): 1512-5.

14. Jurgen Schimidt, Brunhlide Voigt and Gunter Adam. 2- Deoxybrassinolide - A naturally occurring brassinosteroid from Apium graveolens. Phytochemistry, 1995; 40(4): 1041- 1043. https://doi. org/10.1016/0031-9422(95)00363-C

15. Vinod K Ahluwalia Furanocoumarin glucosides from the seeds of Apium graveolens. Phytochemistry, 1988; 27(4): 1181-1183. https://doi.org/10.1016/00319422(88)80298-X

16. Garg SK, SR Gupta and ND Sharma. Apiumoside, a new furanocoumarin glucoside from the seeds of Apium graveolens. Phytochemistry; 1979; 18: 1764-1765. https://doi.org/10.1016/0031-9422(79)80214-9

17. BahAr, A Tanveer, A, Varsheney, M and Alamkhan, S. Hepatoprotective activity of two plants belonging to the Apiaceae and the Euphorbiaceae family. J. of Ethnopharmacology; 2002; 79(3): 313-6. https://doi. org/10.1016/S0378-8741(01)00392-0

18. Garg SK, SR Gupta, ND Sharma. Apiumetin- A new furanocoumarin from the seeds of apium graveolens. Phytochemistry, 1978; 17: 2135-2136. https://doi. org/10.1016/S0031-9422(00)89300-0

19. Lenzen, $\mathrm{S}$. The mechanisms of Alloxan and streptozoocin induced diabetes, Deabatologica, 2008; 51:216-226. https://doi.org/10.1007/s00125-007-0886-7

20. Peipei Yin, Yu Wang, Lingguang, Yang, Jinling Sui and Yujun Liu. Hypoglycemic effects in alloxan-induced diabetic rats of the 3 phenolic extract enriching ellagic acid, kaempferol and their 4 derivatives from Mongolian oak cups P. Molecules, 2018; 23: 1046; https://doi.org/10.3390/molecules

21. Takasu, N Aswaa, T, Komiya, I Nagasawa, Y and Yamada, T. Alloxan induced DNA strand breaks in pancreatic islets.; J. Boil.Chem., 1991; 266: 2112-2114.

22. Sakurai, $K$ and Ogiso, T. Effect of ferritin on $\lambda$ DNAstr and breaks in the reaction system of alloxan plus NADPH-cytochrome $\mathrm{P} 450$ reductase: ferritins role in diabetogenic action of alloxan., Biol. Pharm. Bull., 1995; 18: 262-266. https://doi.org/10.1248/ bpb. 18.262

23. Ankur Rohilla and Shahjad Ali, Alloxan Induced Diabetes, Mechanisms and Effects, 2012; 3(2): 819823.

24. Susheela T Balaravi P, Theophilus J, Narender T, and P.U.M. Evaluation of hypoglycemic and antidiabetic effect of Melia dubia CAV fruits in mice. J. Current Science, 2008; 9(49): 1191-1195

25. Yaser AJ, Muneer A, Abdelhafid B, Daoudi CS A LH. Chemical and phytochemicalanalysis of some diabetic plants in Yemen. International Research Journal of Pharmacy, 2013; 4: 72-76. https://doi. org/10.7897/2230-8407.04915

26. Choate CJ. Modern medicine and traditional Chinese medicine Diabetes Mellitus, J. Chin Med., 1998; 1.

27. Handa SS, Kanuja SS, Longo, and Devdutt R. Extraction technologies for medicinal and aromatic plants 
international center for science and high technology available on line information, 2008. https://www. unido.org.

Kanter M, Meral I, Yener Z, Ozbek H, and Demir $\mathrm{H}$. Partial regeneration/ proliferation of the -cells in the islets of langerhans by Nigella sativa $L$. in sterptozotocin-induced diabetic rats. Tohoku.; J. Exp. Med.; 2003; 201: 213-1. https://doi.org/10.1620/ tjem.201.213

29. Veermanic C, Pushpavalli G, and Pugalendi KV. Antihyperglycemic of Cardispermum halicacabum Linn. Leaf extract on STZ induced diabetic rats.; J. Appl. Biomed., 2008; 6: 19-26. https://doi.org/10.32725/ jab.2008.003
30.

Kubish HM, Vang J, Bray TM, and Phillips JP. Targeted over expression of $\mathrm{Cu} / \mathrm{Zn}$ superoxide dismutase protects pancreatic beta cells against oxidative stress. Diabetes, 1997; 46: 1563-1566. https://doi. org/10.2337/diacare.46.10.1563

31. Naziroglu M and Cay M. Protective role of intraperitoneally administered vitamin $\mathrm{E}$ and selenium on the oxidative defense mechanisms in rats with diabetes induced by streptozotocin.; Biol. Stress Elem. Res., 2001; 47: 475-488.

32. Farnsworth NR and Segelman AB. Hypoglycemic Plants. Tile and Till. (Eli Lilly and Company), 1971; 57(3):52. 